\title{
Citizenship and Voting: Experiences of Persons With Intellectual Disabilities in Sweden
}

Anette Kjellberg and Helena Hemmingsson

\section{Linköping University Post Print}

\section{Tweet}

N.B.: When citing this work, cite the original article.

This is the pre-reviewed version of the following article:

Anette Kjellberg and Helena Hemmingsson, Citizenship and Voting: Experiences of Persons With Intellectual Disabilities in Sweden, 2013, Journal of Policy and Practice in Intellectual Disabilities, (10), 4, 326-333.

which has been published in final form at:

http://dx.doi.org/10.1111/jppi.12056

Copyright: Wiley-Blackwell http://eu.wiley.com/WileyCDA/Brand/id-35.html

Postprint available at: Linköping University Electronic Press http://urn.kb.se/resolve?urn=urn:nbn:se:liu:diva-102848 
Citizenship and voting - experiences of persons with intellectual disabilities in Sweden

Authors: Anette Kjellberg, PhD, Helena Hemmingsson, Professor.

\author{
Anette Kjellberg \\ Linköping University \\ Faculty of Health Sciences \\ Department of Social and Welfare Studies \\ SE-601 74 Norrköping \\ Sweden \\ Telephone: + 4611363279 \\ Telefax: + 4611125448 \\ E-mail: anette.kjellberg@.liu.se
}

Helena Hemmingsson

Linköping University

Faculty of Health Sciences

Department of Social and Welfare Studies

SE-601 74 Norrköping

Sweden

Telephone: + 4611363565

Telefax: + 4611125448

E-mail: helena.hemmingsson@.liu.se

\title{
Corresponding author:
}

Anette Kjellberg

Linköping University

Faculty of Health Sciences

Department of Social and Welfare Studies

SE-601 74 Norrköping

Sweden

Telephone: + 4611363279

Telefax: + 4611125448

E-mail: anette.kjellberg@.liu.se

Keywords: intellectual disabilities, general election, participation, qualitative, Sweden

Running title: Citizenship and voting 


\begin{abstract}
Citizenship and participation in society have been emphasised as important for persons with intellectual disabilities in Sweden for four decades. The aim of the study was to describe, from a longitudinal perspective, how persons with intellectual disabilities experience citizenship and voting. The characteristics of becoming and being a voter were also identified. Thirteen women and seven men, aged 22-55 years on the first interview occasion in 1998, were interviewed three times in regard to general elections in Sweden during the period 19982006. A constant comparative method was used in the data analysis. Two thirds of the participants voted in at least one of the three elections and a group of seven people did not vote at all. Age and significant persons were the most crucial factors for voting. The characteristics of a voter were having the idea and belief that one should vote as a citizen, and having experience of voting so that one knew how to do it. In both these cases, significant persons and age were of importance. The authors suggest that the development of Swedish social policy may have influenced the voting behaviour since people born during the 1940s and 1950s voted more often than people born during the 1960s and 1970s. Additionally, the social network may enable persons with intellectual disabilities to make full use of their right to exercise political citizenship and to vote.
\end{abstract}




\section{Introduction}

In Sweden, and in other Western countries, several reforms have been implemented to develop and improve living conditions for people with intellectual disabilities. The implementation of the normalisation principle in Sweden during the 1960s can be considered as a prerequisite for establishing citizenship for people with intellectual disabilities (Nirje, 1992, 2003; United Nations, 2006). Marshall (1964) states that there are three types of citizenship. All individuals are equal before the law, i.e. they have civil citizenship. Political citizenship implies the right to vote in general elections. Welfare for all citizens, such as the rights to education and social welfare, is included in social citizenship. The Convention on the rights of persons with disabilities (CRPD) implies that persons with disabilities should be viewed as 'subjects' and should be capable of making choices and determining their own lives. Inclusion in society and participating on an equal basis to all other citizens, are rights that are also included. Participation in political and public life, which is the subject of article 29, guarantees that voting procedures and materials will be accessible, and states that the person should be able to decide if assistance is needed when voting. The environment should also encourage persons with disabilities to participate in public affairs (United Nations, 2006). The introduction of the normalization principle became the starting point for humane treatment of persons with intellectual disabilities in Sweden. The principle implied that the living conditions of persons with intellectual disabilities should be equal to those of other citizens in Sweden (Nirje, 1992, 2003). Over the years, several official reports and laws have been implemented. They have supported participation in daily life and in society for persons with intellectual disabilities, and have adopted principles such as influence, selfdetermination, participation and accessibility (SFS, 1967:940; SFS, 1985:568; SFS, 1993:387; SOU, 1976:20; SOU, 1991:46; SOU, 1992:52). Current Swedish legislation, the Swedish Act concerning Support and Service for Persons with Certain Functional Impairments (SFS, 
1993:387), states that persons with intellectual disabilities should be able to influence their own lives. The service that people receive, according to this law, should promote their participation in social life, such as, for example enabling them to vote. Since 1989, political citizenship has been granted to persons with intellectual disabilities in Sweden; earlier they were classified as minors (Fälldin, 1996). In Sweden there is no registration to vote and every Swedish citizen, of $\mathbf{1 8}$ years and over, currently or previously domiciled in Sweden is entitled to vote (SFS, 1974:152). Traditionally, polling is heavy in Sweden and voting is seen more or less as a duty for citizens. During 1960 to 2006 the turnout in general elections in Sweden was $81-94 \%$ (SCB, 1921-2006).

The research on this subject is sparse and few studies have been performed in relation to voting and adults with intellectual disabilities. Redley (2008) performed a literature review on the right to vote for people with intellectual disabilities. He found that people with intellectual disabilities were under-represented in general elections. In a data-based study, Keeley, Redley, Holland, and Clare (2008)

investigated voting among people who received intellectual disability services in England and found that over $80 \%$ of the people using the services did not vote in the 2005 general election. A predictor of voting was living in a household with at least one other active voter. 1994 election in Sweden Tideman (2000) found that $31 \%$ of people with intellectual disabilities voted, compared with $86 \%$ in the general population. The EU project MOTE was initiated in 2008 and ended in 2010. The purpose for the project was to empower citizenship for people with intellectual disabilities and increase their participation in political elections. The project focused on developing educational programmes on politics, political rights and voting, for people with intellectual disabilities. Six European countries were involved in the project: Denmark, Hungary, Ireland, Italy, Malta and Spain. Data included 20 interviews from each country with people with learning disabilities, focusing 
on political participation. In addition, the project also raised societal awareness on the target group's political rights through contact with political parties, professionals and families. The outcomes of the project have promoted cooperation between European disability organisations as well as collaboration between European public institutions responsible for public and political life of nations (MOTE project, 2008).

However, the reasons for low participation, and how people with intellectual disabilities experience voting need to be further explored. To our knowledge, no other study has been performed that involves interviewing people with intellectual disabilities about their experiences regarding citizenship and voting. Therefore, the overall aim of this study is to describe, from a longitudinal perspective, how persons with intellectual disabilities experience citizenship and voting. The characteristics of becoming and being a voter are also identified.

\section{Methods}

Design

A longitudinal design (Kielhofner, 2006) was adopted in which participants were interviewed on repeated occasions about three successive general elections.

\section{Ethical considerations}

The standard ethical principles in humanities and social sciences outlined by the Swedish Research Council (Vetenskapsrådet, 2002) were followed. Before obtaining informed consent from the participants, efforts were made to provide concrete information regarding the aim of the study and the focus of the interview questions. The interviewer's strategy was to give information about the study in an easily comprehensible way. The participants were informed that participation in the study was voluntary and that they could discontinue the interview whenever they liked. The first and second interviews were concluded by asking if the interviewer could come back and conduct another interview. 


\section{Participants}

Criteria for inclusion of the participants in the present study were that they should : (a) be adults, with moderate to mild intellectual disabilities (Göransson, 1993; Kylén, 1997; American Psychiatric Association, 2000), (b) be receiving service in line with the Act concerning Support and Service for Persons with Certain Functional Impairments (SFS, 1993:387), (c) have been included in an earlier study by Kjellberg (2002a) reporting how 23 people with intellectual disabilities conceived citizenship, and (d) accept to participate in interviews at three occasions. The selection procedure is described in detail in an earlier study (Kjellberg, 2002b). The present longitudinal study comprised 13 women and seven men, aged 22-55 years. All participants were receiving a disability benefit from the social insurance system, lived in supported accommodation, and attended activity centres during the day.

\section{Data collection}

The semi-structured interviews were performed by the first author at the time of the general elections in Sweden in 1998, 2002 and 2006 in order to ensure that the issue was relevant for the participants. Every participant was interviewed three times, resulting in a total of 60 interviews. Most of the 60 interviews were performed within three weeks after each general election. A few of the interviews were administered later for logistical reasons but no later than five weeks after the elections. Most of the interviews took place during the day, in the daily activity centre, where the participants worked. A few of the interviews were held in the participant's home. These settings were natural and well-recognized places for the participants, and enhanced the ecological validity for obtaining valid information.

The same semi-structured interview guide with open-ended, descriptive questions (Taylor \& Bogdan, 1998) was used all three times. The questions focused on the following areas: participants' area of interest in the societal and political sphere; how the participants were 
updated about what was going on in society, and their experiences of voting. Using a semistructured guide allowed the interviewer to adapt the interviews to each participant. Applying the same interview guide at each occasion made it easier to analyse the data from a longitudinal perspective.

The interviewer tried to develop a conversation in an atmosphere that stimulated the informants to describe their experiences from their own point of view. The interviewer's strategy also involved probing techniques (Taylor \& Bogdan, 1998) such as presenting the questions in a concrete and easily comprehensible way, being an active listener, and asking for clarification and concrete examples when necessary. Follow-up questions were used throughout the interviews. A few participants required more clarification than others. For these participants the interviewer gave concrete examples, for example, offering possible alternative ways of voting. In some situations when the participants answered in a laconic way, newspaper cuttings of politicians were used in order to facilitate the dialogue (Booth \& Booth, 1997). The participants started to reflect upon the cuttings and they continued talking about their own experiences regarding the election. Each interview lasted between 30 and 60 minutes and was audio-taped and transcribed verbatim.

\section{Data analysis}

In the data analysis, a constant comparative method was used (Bogdan \& Biklen, 2003). The starting point for the analysis was to read and reread the transcripts several times to get an overall understanding of the material. Thereafter the interviews from 1998, 2002 and 2006 were analysed separately for each participant, with the primary focus on whether or not the participants had voted during the particular period. Based on how many times the participants had voted in the three general elections they were divided into three groups. The first was the voting group; these participants voted on all three occasions, 1998, 2002 and 2006. The next group was the inconsistent voting group; they voted or did not get the 
support they needed for voting and a few of the participants abstained from voting. All of them had voted once or twice. The third was the non-voting group. These participants did not vote in any of the three elections. These three groups became the structure for organizing the personal characteristics for each participant. The personal characteristics were gender, age, intellectual and other impairments. The participants' age was coded into the preintegration generation and the first integration generation (Gustavsson, 1998). The first integration generation was born during the 1960s and 1970s and had experience of the Swedish welfare system regarding democratic rights to participate in society like all other citizens in Sweden, for example by voting. The pre-integration generation was born during the 1940s and 1950s, i.e. before normalization and democratic work started in Sweden. This group of people was previously excluded from society and often lived their lives in closed institutions and did not receive the full right to vote until 1989 (Fälldin, 1996).

Thereafter, significant persons were identified for each participant. In this study they were defined as people who were important to the participants in terms of having political discussions with and getting support in the voting process including family members as well as non-family members. The family members included were parents, siblings, grandparents, nephews, and partners. The non-family members included friends with ID, staff members at home and at work, resource persons, politicians, neighbours, and course-leaders. The analysis was based on the total number of significant persons the participants talked about during the three interviews. Four or more significant persons counted as "many", while "few" meant having 2-3 significant persons who supported the voting process.

The next step in the analysis was to compare similarities and differences within each group and between groups focusing on the participants' experiences of citizenship and voting. Data for each participant was first coded in a line by-line procedure and compared between the three different occasions for data collection (Bogdan \& Biklen, 2003). During this step we 
found that participants described the experience of voting as well as what facilitated or hindered them from voting. Some participants provided reasons for voting or not voting. The codes identified were then grouped together on a more general level and compared within each group, and finally between groups, e.g. the voting group, the inconsistent voting group, and the non-voting group. The final step of analysis resulted in an identification of characteristics for becoming and being a voter (Bogdan \& Biklen, 2003). These characteristics were carefully checked against all existing data to ensure they were based on the interviews. Peer examination was conducted to investigate the credibility of the analysis by a researcher who was experienced in qualitative methods (Patton, 2002).

The participants were given pseudonyms. "P" and "I" were used as abbreviations for Participant and Interviewer. The quotations were chosen to give a broad view of the group and should be regarded as typical for the whole group. In order to exemplify the participants' change or lack of change over time there are two to three quotations for each participant, representing their views in 1998, 2002 and 2006 respectively.

\section{Results}

The results section presents the voting group, the inconsistent voting group, and the nonvoting group followed by characteristics of becoming and being a voter. Table 1 gives an overview of the participants' characteristics, voting, and number of significant persons.

Insert Table 1 about 1 here

\section{The voting group}

The participants in this group who voted in all three general elections were a mix of persons from the pre-integration generation and the first integration generation. Their social networks 
included many significant persons, as shown in Table I. Significant persons who were often mentioned in regard to voting were parents. For example, Sue, who represented the first integration generation in the voting group, referred on all three occasions to her parents, who had instilled in her the tradition of voting. She described this in 1998:

I: Why did you decide to vote?

P: I am used to this. It is a habit from the time I lived with my parents.

I: So you have voted before?

P: Oh yes.

In 2002 she said that: “I think voting is something everybody should do." Sue was familiar with voting and managed to vote independently. Thus, she did not have to rely on others to exercise her political citizenship, although her family members often went to the polling station together. She and her partner went together and voted at the post office in 1998. At the next election she went by herself to the polling-station, and in 2006 she went with her parents. The social support took many forms and could, as well as parents, be anything from political discussions with others to practical planned counselling and guidance sessions and having support to get access to vote information. For example, David, a man of the pre-integration generation, described how a staff member in 2002 showed him easy-reading material related to the election. Before the election that year he had been in contact with a politician, and this influenced his decision to vote. He described this experience: "I was in their booth downtown and discussed some political issues with a politician." He received some easy-reading brochures from the politician:

I: Was this material useful for you?

P: Yes I can read. But many of my friends cannot. If the brochures had been recorded on tape it would have been better for them. 
On all three occasions David talked about his resource person. This support was crucial because of his financial situation, but also gave opportunities for discussing political issues. Discussions with staff members concerning voting were also described on all three occasions. Besides opportunities to discuss politics with significant persons, having experiences of voting, and knowing how to do it were also emphasised by participants in the voting group. Jane, from the pre-integration generation, described on all three occasions how she went to the same polling station alone. She said that her partner voted also. This dialogue is from 1998:

\author{
P: I knew it was the polling-day and that I should vote, so I \\ went to the polling-station by myself. \\ I: Had you voted before? \\ P: Yes I had. So I knew how to do it.
}

Like David, Jane also referred to political discussions she had been involved in or had come across. She was interested in politics, and at the activity centre she had participated in a club where social issues were discussed. The club consisted of staff members and people with intellectual disabilities. The club had invited politicians to the centre to provide information about political issues in connection to the general elections. In 2006 Jane described how she had seen politicians in town but she had not tried to talk to them. She recognized them from political debates on television that she followed and she said: "I watch TV instead. The politicians have been on TV several nights in a row." Besides discussions with real persons, the media was used as a means of obtaining information about political matters relevant to the upcoming election.

\title{
The inconsistent voting group
}


The participants in this group showed a varied pattern throughout the years regarding voting. Most of the participants were from the pre-integration generation and had few significant persons, as can be seen in Table 1.

The importance of being introduced to voting and knowing how to do it was also evident in the inconsistent voting group. The following quotations show how Mary, one of the participants from the pre-integration generation, became a voter when she changed accommodation and received the support she needed. In 1998 she said: "I did not vote this time. I had never voted before either." She stated in 2002 that: "No I was not at the pollingstation. I do not like to vote at all." She moved to a new group home and this influenced her to vote. So in 2006, she and a group including staff members and persons with intellectual disabilities walked together to the polling-station. Mary declared: "He [a staff member] helped me to do it [the voting procedure]. He was very good." The support included practical guidance on how to act in the polling- station.

Some participants from the first integration generation were not accustomed to voting. One of them, Sarah, said in 1998 that she had not voted: "My mother does not think I should vote." Sarah moved from her parent's house to a group home, and in 2002 and 2006 she went to vote with staff from the group home. In 2006 she said: "I was accompanied to the polling station by a staff member who works where I live."

This group, as well as the voting group, described how political discussions with significant persons or in the media influenced them to vote or not to vote.

For example, Peter, from the pre-integration generation, said in 1998 that he thought that the politicians were just "talking" so that was why he did not vote. He continued: "Before the election they [the politicians] promise a lot, and afterwards they do what they want."

He went to the polling station with his nephew in 2002: 
P: My nephew's husband and my sister discussed the coming election

... I got a sudden idea and decided to vote.

I: How come you decided that?

P: I saw on TV that it was very even between the parties.

The quotation shows that Peter had developed an interest in politics and that he wanted to influence the poll by voting. In 2006 he voted with the director at the group home. The reason for voting this time was the same as in 2002 . He said: "I voted to get good people as politicians."

Reasons for not voting could be political, but for some there were practical obstacles such as being away on a trip or doing other things on the polling day, as Robert, one of the first integration generation persons in the group said: "I never got round to voting this time [2006]. I was at my mother's house." Robert said in 1998 that he had voted at the pollingstation with his father: "Yes I wanted to vote. I think it is important." In 2002 he said that he had a friend who had voted and that they had discussed political questions at home, and based on these exchanges of views he had decided not to vote this time.

\section{The non-voting group}

The participants in this group did not vote in any of the general elections. Most of the participants represent the first integration generation, and the significant persons were almost equally distributed, from few to many, as shown in Table 1.

Some of the participants in this group felt that voting was too difficult for them, and some described their own or their family's lack of political interest as the reason for not voting. In 1998, Paula, from the pre-integration generation, said that neither she nor her mother had voted. She added: "You see I have difficulties with writing. I heard that my 
mother's neighbour also skipped voting." Paula had moved to a new group home because she needed more support from staff but this did not change her voting behaviour in 2002. She said: "No, I think it is too difficult for me [to vote]. I have never done such a thing by myself." In 2006 she also said that she had decided not to vote:

"I have not been involved in it. I do not care about the election."

Andrew represented the first integration generation. He did not vote in any of the elections. He had no interest in politics and did not think voting would make any difference. In 1998 he said: "I do not think it is worth it. It is not going to be better because of that." In 2002 and 2006 he expressed the view that the election was "not of interest" to him.

There were also participants in this group who declared that they had wanted to vote but had not received the support needed. Phil, from the first integration generation, was one such person. In 1998 he said: "No, I did not vote. I think that was a mistake."

In 2002 he said: "They [the staff] had no time to come along with me. I cannot handle it by myself. I have never been there [to the polling-station].” Based on his former experiences it was not surprising that in 2006 he seemed disillusioned and had given up on the possibility of getting support. He stated: "I am tired of this rubbish [voting]. It is the same every time. And now there is going to be a new prime minister. It is questionable if this will work." This quotation shows that Phil, although he mentioned no intention to vote, had an opinion and followed the main political issues.

\section{Characteristics of becoming and being a voter}

About two thirds of the participants had voted in at least one general election during the research period. Based on participant experiences, characteristics were identified for becoming and being a voter in general elections. Analysis revealed that one characteristic of the voters was having the idea that voting was important and something you should do as a 
citizen. For some individuals, parents had passed over a political interest and the habit of demonstrating citizenship by voting. For others, these ideas had been introduced later, in discussions with other significant persons such as relatives, peers or staff at activity centres. The engagement of those significant persons, in combination with information from the media, seemed to be crucial both for arousing and sustaining participants' political interest. The next main characteristic of voters revealed in the analysis was being comfortable with the practical act of voting and knowing how to do it. People in the voting group all had experience of voting and emphasized that they knew how to do it. The importance of being given an introduction to voting and practical guidance was also evident in the inconsistent voting group, as for example with Mary, who first declared she was uninterested in elections but then became a voter when she received the practical support she needed. Reasons for not voting in the inconsistent voting group were otherwise typically related to practical issues, such as being occupied with something else on the actual day. Reasons for not voting in the non-voting group were accordingly associated with lack of political interest or a belief that voting was meaningless, problems in understanding and managing voting, as well as lack of experience and adequate support. Thus, the characteristics of a voter were having the idea and belief that one should vote as a citizen, and having experience of voting so that one knew how to do it. In both these cases the engagement and support of significant persons, and belonging to the pre- integration generation were of the utmost importance.

\section{Discussion}

The aim of the current qualitative study was to describe, from a longitudinal perspective, how persons with intellectual disabilities experience citizenship and voting. The study also focused on the characteristics of becoming and being a voter. One of the characteristics having the idea and belief that one should vote as a citizen - was more common in the preintegration generation. This indicates that the participant's age was of importance in relation 
to voting. This can be discussed in terms of development of Swedish social policy. Most of the persons in the voting group and the inconsistent voting group were from the preintegration generation, i.e. they were born during the 1940s and 1950s.

The socio-political development during the 1960s in Sweden was dynamic. The normalization principle (Nirje, 1992) was introduced. A law (SFS, 1967:940) based on this principle was adopted to secure integration in society for people with intellectual disabilities. The importance of group homes and day centres in society was stressed in the law, and deinstitutionalization started. However, in 1989 all people with intellectual disabilities in Sweden were granted the legal right to vote, i.e. they received political rights as defined by Marshall (1964). It was during these years that the 'pre-integration generation' in the current study became adults. This breakthrough for inclusion in society may also have influenced the participants and their families in the present study, with the result that the participants decided to vote in general elections, and in so doing were regarded as being the same as anyone else in society. Being born during the 1940s and 1950s and being brought up during this dynamic development of living conditions for people with intellectual disabilities might imply that discussions about political citizenship were more central for the pre-integration generation than for the first integration generation since their rights as citizens might be seen as taken for granted. The longitudinal design made it possible to compare the pre-integration generation and first integration generation in the current study with the equivalent age groups in the general elections in Sweden. This comparison revealed that the two groups showed the same tendency over time for voting or not voting. A similar age group in the general population as the one in this study, termed the pre-integration generation, usually voted approximately $5 \%$ more often than the younger people did in the general elections in Sweden in 1998, 2002 and 2006 (SCB, 1998, 2002, 2006). 
However, belonging to the pre-integration generation also implies that the individual has had more time to be introduced to political citizenship by significant others. The results also suggest that significant persons may support people with intellectual disabilities to participate in political life, as stipulated in the Convention on the Rights of Persons with Disabilities (United Nations, 2006). Seven of the participants who had many significant persons voted on two or three occasions, as seen in Table I. This could be interpreted to mean that significant persons are important for people with intellectual disabilities when voting in general elections, and give them the opportunity to exercise citizenship.

A parallel to this is found in the study by Keeley et al. (2008) which showed that the most significant predictor for whether people with intellectual disabilities would vote was living in a household with at least one other voter. Of interest, is that three participants who had many significant persons, however, decided not to vote. Not voting, or returning a blank ballot paper is also a democratic right, and the social network need be supportive of this decision too.

The Swedish National Institute of Public Health reports that people with intellectual disabilities in Sweden have a lower income than the norm, and most have a limited social network, consisting mostly of support staff and relatives (Statens Folkhälsoinstitut, 2008:13). Additionally, people with intellectual disabilities typically have a lifelong need of support in everyday life (Wehmeyer, Bersani, \& Gagne, 2000). Widening the social network may give more opportunities for people with intellectual disabilities to find persons with whom they can discuss political issues and voting, and who, if needed, will accompany them to the polling station.

However, just to focus on the number of significant persons would be oversimplifying the whole context. There is also an issue of the quality of the social contacts that people with intellectual disabilities have. Attitudes and knowledge may be decisive for the network's way 
of handling communication with people with intellectual disabilities. If staff members have knowledge about the CRPD (United Nations, 2006) and work in line with this convention, this will facilitate the process for persons with intellectual disabilities to become participatory citizens. This may imply education on voting and giving concrete support on how to vote, i.e. practical guidance in the polling station, active communication, and encouragement and involvement of persons with intellectual disabilities to participate in political and public life. Keeley et al (2008) point out that the attitudes of heads of household were critical in influencing the voting of people with intellectual disabilities. Redley (2008) proposed a "functional approach" for supporting persons with intellectual disabilities in voting in general elections. This implies that it is important for persons with intellectual disabilities to be involved in conversations regarding voting. This is in agreement with the current study's results regarding significant persons being defined as people who are important to the participants in terms of having political discussions and getting support in the actual voting process. In addition, Redley (2008) emphasised that staff members play a crucial role in actively initiating and discussing voting with persons with intellectual disabilities. The present study supports the "functional approach" and suggests that relatives should also be included in this approach since all except two of the participants had at least one family member who had been important for them in the voting process. The EU project MOTE also included families in the work to increase political citizenship for persons with intellectual disabilities (MOTE project, 2008).

An implication that can be made from the study is that staff and family members are important resources for enabling persons with intellectual disabilities to be involved in political and public life and develop political citizenship. It is crucial for the staff to support the target group in broadening their social networks, since a wider network 
gives more opportunities to discuss political issues and may encourage the group in exercising their rights in public life. Another recommendation is that the rights and duties the persons with intellectual disabilities have in society must be a focus even in everyday life between general elections, since participation in decision-making is something that should permeate daily activities all-year-round in several environmental contexts.

\section{Limitations and future research}

Some methodological issues need to be considered. Like other qualitative research studies the results could not be generalized to other populations nationally or internationally but is rather aimed at increasing the understanding of the phenomena studied. The longitudinal approach (Kielhofner, 2006), involving collecting data on three general elections from 20 participants, was useful since it provided an opportunity to understand patterns of change of experiences of citizenship and voting over time. Interviewing people with intellectual disabilities is a methodological challenge (Finlay \& Lyons, 2002; Perry \& Felce, 2002). Many could describe in detail what they had experienced, such as the act of voting, but were less able to describe their thoughts and the reasons for their actions (i.e. abstract reasoning). This in turn influences the depth and richness of data available for analysis. Nevertheless, to perform interviews with people with intellectual disabilities is crucial in order to gain insight and knowledge on citizenship and on voting from their perspective.

Since existing knowledge on citizenship and voting in regard to people with intellectual disabilities is limited, further research is warranted. It is necessary to conduct studies with research designs whose results have the potential to be generalized to other populations. A possibility would also be to conduct voting studies using a mixed-methods design, incorporating qualitative and quantitative data. This design would provide information 
from different types of data and get deeper understanding of the citizenship and voting for persons with learning disabilities.

The present study should be viewed as an attempt to describe how CRPD, particularly article 29 (United Nations, 2006), has been realized and experienced by persons with intellectual disabilities. Another interesting point for further studies would be to investigate, nationally and internationally, if the same pattern that was found regarding voting in the pre-integration generation and the first integration generation is similar or different in other groups of persons with disabilities.

Investigating professionals', authorities' and politicians' views on how to realize the CRPD (United Nations, 2006) in practice for the target group would also be of interest. Increasing knowledge about the barriers and facilitators for enabling persons with intellectual disabilities to exercise their political rights is an urgent issue. The present study should be viewed as a contribution to this knowledge based on the perspectives of persons with intellectual disabilities. 


\section{References}

American Psychiatric Association (2000). Diagnostic and statistical manual of mental disorders DSM-IV TR. ( $4^{\text {th }}$ ed. text revision). Washington DC: American Psychiatric Association.

Bogdan, R.C., \& Biklen, S.K. (2003). Qualitative research for education: An introduction to theories and methods. (4 ${ }^{\text {th }}$ ed.). New York: Pearson Education Group.

Booth, T., \& Booth, W. (1997). Making connections: a narrative study of adult children of parents with learning difficulties. In C. Barnes \& G. Mercer (Eds.), Doing Disability Research (pp. 123-141). Leeds: Disability Press.

Finlay, W.M.L., \& Lyons, E. (2002). Acquiescence in interviews with people who have mental retardation. Mental Retardation, 40, 14-29.

Fälldin, K. (1996). God man eller förvaltare [Administrator or trustee]. Stockholm: LT:s förlag.

Gustavsson, A. (1998). Inifrån utanförskapet. Om att vara annorlunda och delaktig [Insiders' Perspectives on Being an Outsider]. Stockholm: Johansson \& Skyttmo förlag.

Göransson, K. (1993). Hur förståelsen av verkligheten utvecklas [How our understanding of reality develops]. Stockholm: Stiftelsen ALA, Handikappinstitutet.

Keeley, H., Redley, M., Holland, A.J., \& Clare, I.C.H. (2008). Participation in the 2005 general election by adults with intellectual disabilities. Journal of Intellectual Disability Research, 52, 175-181.

Kielhofner, G. (2006). Research in occupational therapy. Methods of inquiry for enhancing practice. Philadelphia: F.A. Davis Company.

Kjellberg, A. (2002a). Being a citizen. Disability and Society, 17, 187-203.

Kjellberg, A. (2002b). More or less independent. Disability \& Rehabilitation, 24, 828-840. 
Kylén, G. (1997). Begåvning och begåvningshandikapp [Intellect and intellectual handicaps]. Stockholm: Stiftelsen ALA, Handikappinstitutet.

Marshall, T.H. (1964). Class, citizenship, and social development. New York: Doubleday.

MOTE project (2008). Retrieved January 28, 2013, from http://www.myopinionmyvote.eu

Nirje, B. (1992). The Normalization principle papers. Uppsala University: Centre for Handicap Research.

Nirje, B. (2003). Normaliseringsprincipen [The Normalization Principle]. Lund: Studentlitteratur.

Patton, M.Q. (2002). Qualitative research and evaluation method. ( $3^{\text {rd }}$ ed.). London: Sage.

Perry, J., \& Felce, D. (2002). Subjective and objective quality of life assessment: Responsiveness, response bias, and resident: Proxy concordance. Mental Retardation, 40, $445-456$.

Redley, M. (2008). Citizens with learning disabilities and the right to vote. Disability \& Society, 23, 375-384.

SCB [Statistics Sweden]. Valdeltagande bland kvinnor och män 1921-2006 [Participation in elections among women and men 1921-2006]. Retrieved January 1, 2011, from http://www.scb.se

SCB [Statistics Sweden]. Valdeltagande i riksdagsvalet 1998, 2002, 2006 efter kön och ålder [Participation in the general election 1998, 2002, 2006 regarding sex and age]. Retrieved January 9, 2011, from http://www.scb.se

SFS [Swedish Statute Book] 1967:940. Lag angående omsorger om vissa psykiskt utvecklingsstörda [The special services act].

SFS [Swedish Statute Book] 1974:152. Regeringsformen [The instrument 
of government].

SFS [Swedish Statute Book] 1985:568. Lag om särskilda omsorger om psykiskt utvecklingsstörda [The special services act].

SFS [Swedish Statute Book] 1993:387. Lagen om stöd och service till vissa funktionshindrade [The act concerning support and service for persons with certain functional impairments]. SOU [Swedish Official Report Series] 1976:20. Kultur åt alla. Betänkande av handikapputredningen [Culture for all. Report from the Handicap commission]. Stockholm: LiberFörlag.

SOU [Swedish Official Report Series] 1991:46. Handikapp, välfärd, rättvisa. Betänkande av 1989 års handikapputredning [Handicap, welfare, justice. Report from the 1989 year's Handicap commission]. Stockholm: Allmänna förlaget. SOU [Swedish Official Report Series] 1992:52. Ett samhälle för alla. Slutbetänkande av 1989 års handikapputredning [A society for all. Final report from the 1989 year's Handicap commission]. Stockholm: Allmänna förlaget.

Statens Folkhälsoinstitut [The Swedish National Institute of Public Health] 2008:13. Onödig ohälsa. Hälsoläge för personer med funktionsnedsättning [Unnecessary illness. The health situation for people with disabilities]. Retrieved January 7, 2011, from http://www.fhi.se

Taylor, S.J., \& Bogdan, R. (1998). Introduction to qualitative research methods. A guidebook and resource. ( $3^{\text {rd }}$ ed.). New York: John Wiley \& Sons, Inc.

Tideman, M. (2000). Normalisering och kategorisering. Om handikappideologi och välfärdspolitik i teori och praktik för personer med utvecklingsstörning [Normalization and categorization in disability ideology and welfare policy in theory and practice for people with intellectual disability]. Göteborg: Department of Social Work, Göteborg University, Sweden. 
United Nations (2006). Convention on the rights of persons with disabilities. UN. Retrieved January 7, 2011, from http://www.un.org/disabilities/convention

Vetenskapsrådet [Swedish Research Council] (2002). Forskningsetiska principer inom humanistisk-samhällsvetenskaplig forskning [Principles of research ethics in the humanities and social sciences]. Stockholm: Vetenskapsrådet.

Wehmeyer, M., Bersani, H. Jr., \& Gagne, R. (2000). Riding the third wave: Selfdetermination and self-advocacy into the $21^{\text {st }}$ century. Focus on Autism and Other Developmental Disabilities, 15, 106-115. 
TABLE 1. Participant characteristics, voting and significant persons

\begin{tabular}{|c|c|c|c|c|c|c|}
\hline Group & Gender & $\operatorname{Age}^{\mathrm{a}}$ & $\begin{array}{l}\text { Intellectual } \\
\text { impairment }\end{array}$ & $\begin{array}{l}\text { Other } \\
\text { impairment }\end{array}$ & $\begin{array}{l}\text { Voting in } \\
\text { election }\end{array}$ & $\begin{array}{l}\text { Significant } \\
\text { persons }^{b}(n)\end{array}$ \\
\hline \multirow[t]{5}{*}{ THE VOTING GROUP } & Barbara & pre & mild & & \multirow{5}{*}{$\begin{array}{l}\text { all participants } \\
\text { voted in } 1998, \\
2002 \text { and } 2006\end{array}$} & many $6(2 / 4)$ \\
\hline & Jane & pre & moderate & & & many $5(1 / 4)$ \\
\hline & David & pre & mild & & & many $9(0 / 9)$ \\
\hline & Sue & first & moderate & & & many $8(3 / 5)$ \\
\hline & John & first & moderate & & & many $6(3 / 3)$ \\
\hline \multirow{8}{*}{$\begin{array}{l}\text { THE INCONSISTENT } \\
\text { VOTING GROUP }\end{array}$} & Mary & pre & moderate & \multirow{3}{*}{ motor } & 2006 & few $2(1 / 1)$ \\
\hline & Patty & pre & moderate & & 2006 & few $3(0 / 3)$ \\
\hline & Carol & pre & mild & & 1998 & few $3(1 / 2)$ \\
\hline & Jennifer & pre & moderate & \multirow[t]{3}{*}{ visual } & 2006 & few $3(1 / 2)$ \\
\hline & Peter & pre & mild & & 2002,2006 & many $5(3 / 2)$ \\
\hline & Tim & pre & moderate & & 1998 & few $3(1 / 2)$ \\
\hline & Sarah & first & moderate & \multirow[t]{2}{*}{ motor } & 2002,2006 & few $3(2 / 1)$ \\
\hline & Robert & first & moderate & & 1998,2002 & many $6(1 / 5)$ \\
\hline \multirow{7}{*}{$\begin{array}{l}\text { THE NON VOTING } \\
\text { GROUP }\end{array}$} & Anne & pre & moderate & \multirow{7}{*}{ auditory } & \multirow{7}{*}{$\begin{array}{l}\text { none of the } \\
\text { participants } \\
\text { voted in } 1998, \\
2002 \text { and } 2006\end{array}$} & few $3(1 / 2)$ \\
\hline & Paula & pre & moderate & & & many $5(1 / 4)$ \\
\hline & Julia & first & moderate & & & few $3(1 / 2)$ \\
\hline & Elisabeth & first & moderate & & & few $2(1 / 1)$ \\
\hline & Debra & first & mild & & & few $3(1 / 2)$ \\
\hline & Andrew & first & mild & & & many $7(1 / 6)$ \\
\hline & Phil & first & moderate & & & many $4(1 / 3)$ \\
\hline
\end{tabular}

a 'the pre integration generation' born during the 1940s and 1950s and 'the first integration generation' born during the 1960s and 1970s

${ }^{\mathrm{b}}$ many includes $>4$ significant persons, few includes 2-3 significant persons, within the parentheses the number of family members/non-family members are shown 